\title{
POLA PENDIDIKAN ISLAM DI PONDOK PESANTREN MAHASISWA MIFTAHUL KHOIR BANDUNG DALAM MEMBENTUK KEPRIBADIAN ISLAMI
}

\author{
Tatang Hidayat ${ }^{1}$, Ahmad Syamsu Rizal ${ }^{2}$, Fahrudin $^{3}$ \\ 1.2.3) Program Studi Ilmu Pendidikan Agama Islam, Fakultas Pendidikan \\ Ilmu Pengetahuan Sosial, Universitas Pendidikan Indonesia \\ J1. Dr. Setiabudhi No. 299 Bandung 40154 Jawa Barat - Indonesia \\ Email: 1tatanghidayat@upi.edu; 2rizal@upi.edu; 3fahrudin59@upi.edu
}

DOI: $10.29313 /$ tjpi.v7i1.3770

Accepted: May 17th, 2018. Approved: July 16th, 2018. Published: July 16th, 2018

\begin{abstract}
The purpose of this present study is to describe the Islamic education system at Miftabul Khoir University Student Islamic Boarding School in the process of establishing Islamic personality. This present study employed a descriptive method and a qualitative approach. Based on the results of the study, the Miftabul Khoir University Student Islamic Boarding School was considered as the Salafi Islamic Boarding School group. In fact, it was indicated by the establishment of religious understanding which was adopted from Miftahul Huda Islamic Boarding School, Tasikmalaya. The purpose of Islamic education at Miftabul Khoir University Student Islamic Boarding School is to raise up leader cadres leaders of people who have Islamic personality and develop the religion of Islam in accordance with their field of expertise.
\end{abstract}

Keywords: System, Islamic Education, Miftahul Khoir University Student Islamic Boarding School, Bandung, and Islamic Personality.

\section{ABSTRAK}

Tujuan penelitian ini untuk mendeskripsikan pola pendidikan Islam di Pondok Pesantren Mahasiswa Miftahul Khoir dalam membentuk kepribadian Islami. Penelitian ini menggunakan metode deskriptif dan pendekatan kualitatif. Berdasarkan hasil penelitian, Pondok Pesantren Mahasiswa Miftabul Khoir termasuk ke dalam kelompok pesantren salafi yang dari segi pemahaman keagamaan menginduk kepada Pondok Pesanren Miftahul Huda Tasikmalaya. Tujuan pendidikan Islam di Pondok Pesantren Mahasiswa Miftahul Khoir memiliki ciri khas dalam mewnjudkan kader pemimpin umat yang memiliki kepribadian Islami dan mengembangkan dinul Islam sesuai dengan kemampuan ilmu yang diperolehnya.

Kata Kunci: Pola, Pendidikan Islam, PPM Miftabul Khoir Bandung, dan Kepribadian Islami 


\section{PENDAHULUAN}

Islam adalah agama sempurna yang mengatur seluruh aspek kehidupan manusia, baik itu urusan hamba dengan Allah Subhānahu $W a$ Ta'ālâ seperti dalam hal ibadah, urusan hamba dengan dirinya seperti dalam hal akhlak dan urusan hamba dengan sesama manusia seperti dalam hal mu'ämalah, qișaș, hudud, jināyah dan yang lainnya. Aturan Islam mencakup hubungan manusia dengan Allah Subhānahu $W a$ Ta'àlâ dan hubungan dengan sesama manusia merupakan bentuk kebaikan untuk manusia sendiri. Abdussalam (2014) menegaskan tanpa terjalinnya antara hubungan manusia dengan Allah dan sesama manusia, maka hidup dan kehidupan manusia akan sengsara dan hina.

Dari kehidupan sosial yang diatur oleh Islam, pendidikan merupakan bidang yang berupaya mengembangkan potensi sumber daya manusia supaya berkualitas untuk menentukan peradaban suatu negeri. Pendidikan Islam akan mempengaruhi terbentuknya sumber daya manusia yang akan menentukan peradaban dengan ciri khas tertentu, yakni peradaban Islam. Oleh sebab itu, kualitas pendidikan yang ada di suatu negeri akan mempengaruhi terbentuknya peradaban negeri tersebut. Pendidikan dalam perspektif Islam tentunya akan berbeda dengan pendidikan dalam perspektif dunia Barat, baik itu dari segi konsep, tujuan, kurikulum, guru, murid, metode, materi hingga evaluasinya. Nata (2011:36) pendidikan Islam adalah pendidikan yang seluruh komponen didasarkan pada ajaran Islam, baik itu tujuan, proses belajar mengajar, pendidik, peserta didik, kurikulum, bahan ajar dan komponen pendidikan lainnya didasarkan pada aturan Islam.

Tujuan pendidikan Islam berbeda dengan tujuan pendidikan Barat, tujuan umum pendidikan Islam menurut Tafsir (2014:51) ialah membentuk muslim yang sempurna atau manusia yang bertakwa, beriman, dan beribadah kepada Allah Subḥānabu $W a$ Ta'ālâ. Adapun Daradjat
(2006:31) menyimpulkan tujuan akhir pendidikan Islam ialah menjadi insān kamil yakni mati dalam keadaan berserah diri kepada Allah Subḥanabu Wa Ta'älâ yang merupakan ujung dari takwa, sedangkan Yusanto Dkk, 2014:65) menegaskan tujuan pendidikan dalam Islam adalah membentuk kepribadian Islami, menguasai śaqafah Islam, menguasai ilmu pengetahuan dan teknologi serta keahlian yang memadai.

Dari uraian di atas, dapat dipahami bahwa tujuan pendidikan Islam adalah sebagai upaya membentuk kepribadian Islami yang terlihat dari pola pikir dan pola sikap yang Islami, menguasai saqafah Islam, ilmu pengetahuan dan teknologi serta memiliki keahlian yang memadai. Abdussalam (2011) melaporkan ada ciri khas paradigma dalam pendidikan Islam yaitu dilandasi dengan paradigma tauhid, yakni paradigma tersebut memandang bahwa alam dan kehidupan sebagai satu sistem yang komprehenshif dan integral yang menempatkan Allah sebagai satu-satunya sentral, landasan, rujukan dan tujuan. Oleh karena itu, apapun yang dilakukan harus ditujukan untuk mengagungkan Allah Subḥānahu $W a$ Ta'ālâ.

Rizal (2014) mencatat bahwa pendidikan Islam berorientasi kepada: Pertama, dunia ke ukbräwi. Kedua, rohani versus badani artinya dalam pembentukan jiwa yang menekankan pada aspek rohani melalui tarkizätun al-nafs. Ketiga, masa lalu dan masa depan artinya di mana pendidikan bertujuan membekali anak-anak didik dengan kemampuan yang akan dihadapi dalam tantangan hidup di masa depan, adapun masa lalu merupakan pendidikan yang dijadikan ibrah bagi sikap, kesiapannya berperilaku dan bertindak membangun kebaikan diri dan masyarakat. Keempat, pendidikan Islam antara membebaskan dan mengikatkan artinya pendidikan menurut Islam untuk kepentingan membebaskan manusia dari tirani manusia, dan mengikat jiwa dengan ikatan yang kokoh yaitu melalui keterikatan pada urusan dengan Allah Subhānahu Wa Ta'álâ (bersifat tetap) dan 
keterikatan pada urusan sesama manusia yang merupakan hasil kesepakatan.

Namun realita pendidikan di Indonesia saat ini sangat mengkhawatirkan dengan terjadi berbagai macam problematika. Fahrudin (2011) mengobservasi karena semakin pesatnya arus globalisasi, informasi dan teknologi ternyata di sisi lain memunculkan problematika baru yang kerap kita temukan pada diri individu dalam suatu masyarakat. Khususnya dalam dunia pendidikan dengan munculnya kenakalan remaja, maraknya minuman keras, narkoba, pergaulan bebas, kekerasan serta berbagai bentuk penyimpangan penyakit kejiwaan, seperti stress, depresi, dan kecemasan, adalah bukti yang tidak ternafikan akibat dampak negatif dari pesatnya arus globalisasi.

Semakin maraknya peredaran dan konsumsi minuman keras di kalangan generasi muda khususnya mahasiswa merupakan hal yang sangat memprihatikan bagi generasi muda. Kurniawan (2016) melaporkan data dalam situs detik.com (9/2/2016) tersangka kasus minuman keras oplosan, Sasongko (45) sudah lama menjalankan bisnis memproduksi miras oplosan yang menewaskan puluhan orang tersebut. Pelanggannya sebagian besar adalah mahasiswa maupun kalangan bawah.

Minuman keras merupakan cikal bakal tindakan kejahatan selanjutnya, sehingga dari minuman keras tersebut ada sebagian mahasiswa yang mulai terjerumus mengkonsumsi narkoba. Hamdi (2016) melaporkan dalam tempo.co (22/9/2016) Kepala Badan Narkotika Nasional Kota Depok Ajun Komisaris Besar Syaefudin Zuhri mengatakan, berdasarkan data survei pengguna narkoba yang dilakukan BNN dan Universitas Indonesia pada 2012, pelajar dan mahasiswa yang sudah menjadi pengguna mencapai enam orang dari 100 orang. Sedangkan yang sudah rutin mengkonsumsi narkoba mencapai tiga orang.

Di sisi lain, perilaku seks bebas di kalangan mahasiswa pun sudah menjadi rahasia umum dengan banyaknya bukti perilaku seks yang dilakukan mahasiswa di berbagai media penyedia informasi. Wiyono (2014) melaporkan data dalam merdeka.com $(16 / 2 / 2014)$ bahwa 54 persen mahasiswa Bandung mengaku sudah pernah melakukan hubungan seks bebas.

Dari uraian di atas tentunya menimbulkan kesenjangan antara tujuan pendidikan dengan realita pendidikan di Indonesia khususnya yang ada di perguruan tinggi. Oleh karena itu, timbul beberapa spekulasi dari para ahli mengenai sebabsebab terjadinya problematika dalam dunia pendidikan. Berdasarkan pendapat para ahli, dapat disimpulkan bahwa penyebab terjadinya problematika dalam dunia pendidikan khususnya pelaksanaan Pendidikan Agama Islam (PAI) di perguruan tinggi disebabkan beberapa faktor:

1. Pendidikan agama hanya terbatas pada masalah penerapan ilmu pengetahuan dan teknologi.

2. Pendidikan agama saat ini banyak dipengaruhi oleh trend Barat yang lebih mengutamakan pengajaran daripada pendidikan moral.

3. Masih adanya anggapan bahwa ilmu pengetahuan adalah bebas nilai, sehingga agama harus ditempatkan di luar struktur ilmu pengetahuan.

4. Pendidikan di perguruan tinggi tidak disentuh inti masalahnya, yakni masalah pokok adalah hati nurani yang tidak mendapat tempat dalam kurikulum pendidikan selama ini.

5. Sistem pendidikan modern semakin nampak arahnya menggiring masyarakat pada debumanisasi Misalnya eksploitasi kelompok yang kuat terhadap kelompok yang lemah, berpikir materialistis, individualistis, dan berperilaku mekanistik seolaholah menjadi budak teknologi bahkan mempertuhan iptek.

6. Kualitas kompetensi pendidik yang belum mumpuni dan peserta didik yang tidak disiplin dalam mengikuti kegiatan pembelajaran. 
7. Pola pendidikan Islam yang belum jelas dan masih cenderung normatif (Syahidin, 2009:4-6), (Muhadjir Effendi dkk, 2002:210), (Langgulung, 1985:122), (Hakim, 2013:6), (Nurlaila, 2011).

Dari beberapa penyebab problematika pendidikan yang telah diuraikan di atas, pelaksanaan PAI yang ada di perguruan tinggi akan menjadi masalah jika tidak di temukan solusi dalam menyelesaikan problematika tersebut, khususnya bagi guru/dosen PAI dan para ahli pendidikan. Problematika tersebut akan berpengaruh terhadap pencapaian tujuan diadakannya pendidikan Islam yakni dalam rangka membentuk kepribadian Islami. Dari ketujuh faktor penyebab problematika pendidikan yang telah diuraikan di atas, penulis memilih poin ketujuh sebagai penyebab problematika utama yang menarik untuk diteliti sebagai upaya mencari solusi dari problematika pendidikan yang ada, yaitu pola pendidikan Islam yang belum jelas dan masih cenderung normatif. Hakim (2013:6) menegaskan dengan pola pendidikan Islam yang sudah jelas, proses pendidikan Islam akan berjalan sesuai dengan tujuan dan tepat sasaran.

Berdasarkan apa yang akan diteliti mengenai pola pendidikan Islam, maka akan muncul sebuah pertanyaan bagaimana pola pendidikan Islam yang jelas dan tidak normatif dalam rangka membentuk kepribadian Islami khususnya di kalangan mahasiswa? Untuk menjawab pertanyaan tersebut perlu diadakan sebuah penelitian sebagai upaya dalam menemukan sebuah pola pendidikan Islam dalam membentuk kepribadian Islami. Oleh karena itu, penelitian ini diupayakan sebagai langkah nyata untuk memecahkan salah satu penyebab problematika dalam dunia pendidikan.

Tempat yang akan menjadi lokasi penelitian adalah sebuah pondok pesantren mahasiswa. Adapun pondok pesantren mahasiswa yang akan menjadi lokasi penelitian adalah Pondok Pesantren Mahasiswa (PPM) Miftahul Khoir Bandung yang berlokasi di Jalan Tubagus Ismail VIII No. 60 Kelurahan Dago Kecematan Coblong Kota Bandung 40135. Berdasarkan hasil pra penelitian, peneliti menemukan halhal yang menarik untuk dikaji lebih mendalam. Peneliti berasumsi bahwa di PPM Miftahul Khoir Bandung ada suatu pola pendidikan Islam yang khas dalam membentuk kepribadian Islami yakni masih mempertahankan nilai-nilai pendidikan tradisional meskipun berada dalam lingkungan gaya hidup modern perkotaan, masih mempertahankan ciri khas pendidikan salafiyah dengan menjadikan kitab kuning sebagai sumber rujukan dalam melaksanakan proses pembelajarannya, masih mempertahankan metode menghafal nażam, ìikir, melantunkan syair-syair keagamaan, lingkungan pesantren yang bersih, santrinya mayoritas adalah mahasiswa dan berasal dari latar belakang yang berbeda-beda. Untuk membuktikan asumsi tersebut perlu diadakan sebuah penelitian. Berangkat dari hal tersebut, peneliti menarik untuk mengangkat judul dalam penelitian ini "Pola Pendidikan Islam di Pondok Pesantren Mahasiswa Miftahul Khoir Bandung Dalam Membentuk Kepribadian Islami”.

\section{METODOLOGI PENELITIAN}

Penelitian ini menggunakan pendekatan kualitataif dan metode deskriptif kualitatif. Brannen (2005:117) mencatat bahwa pendekatan kualitatif merupakan pendekatan yang mengarah kepada pemahaman yang lebih luas tentang makna, konteks tingkah laku dan proses yang terjadi dalam pola-pola pengamatan dari faktorfaktor yang berhubungan. Adapun Ali (2013:131) menyimpulkan bahwa metode penelitian deskriptif digunakan untuk memecahkan atau menjawab suatu permasalahan yang sedang dihadapi pada situasi sekarang.

Penelitian ini bermaksud mencari sebuah pola pendidikan Islam dari data-data 
yang diperoleh di PPM Miftahul Khoir Bandung. Dalam penelitian ini, peneliti fokus terhadap pola pendidikan Islam di PPM Miftahul Khoir Bandung dalam membentuk kepribadian Islami.

Supaya tidak terjadi kerancuan dalam pemahaman dan menghindari pemaknaan yang ganda serta menjelaskan maksud dari kata yang dituju, maka peneliti perlu memberikan penjelasan secara khusus dari maksud judul yang dikemukakan peneliti. Adapun yang dimaksud peneliti dengan judul penelitian "Pola Pendidikan Islam di Pondok Pesantren Mahasiswa Miftahul Khoir Bandung Dalam Membentuk Kepribadian Islami" ini adalah sebuah bentuk sistem pengembangan pribadi yang diberikan guru kepada murid yang mencakup akal, jasmani dan hati yang dilaksanakan di PPM Miftahul Khoir Bandung dalam membentuk kepribadian Islami. Adapun yang dimaksud kepribadian Islami adalah suatu sikap khas yang nampak berupa Akblakul al-Karimah yang berasal dari pola pikir dan pola sikapnya bersandar pada 'Aqidah Islam.

Dalam penelitian ini, dikarenakan menggunakan pendekatan kualitatif, maka peneliti bertindak sebagai instrumen sendiri. Suwandi \& Basrowi (2009:188) menegaskan data yang dikumpulkan dalam penelitian kualitatif meliputi data wawancara, observasi dan dokumentasi. Dalam penelitian ini, peneliti menggunakan teknik wawancara, observasi dan dokumentasi dalam mengumpulkan data.

Dalam penelitian ini, peneliti menggunakan teknik wawancara deskriptif dan struktural, dimana peneliti membuat seperangkat instrumen pertanyaanpertanyaan wawancara yang digunakan, kemudian menggali informasi dan data yang lainnya dengan menggunakan pedoman wawancara. Dalam penelitian ini, peneliti menggunakan teknik observasi partisipasi dan memfokuskan pengamatan terhadap ruang, tempat, pelaku dan kegiatan yakni dengan melihat dan mengamati kegiatan kiai dan santri ketika di masjid, kelas, aula, asrama, kantin, kantor pengurus pesantren, lapang, dan tempat lainnya yang ada di lingkungan PPM Miftahul Khoir Bandung. Dalam penelitian ini, peneliti memperoleh data berupa dokumen Anggaran Dasar/Anggaran Rumah Tangga (AD/ART), brosur, dokumen sejarah pesantren, Garis-Garis Besar Haluan Program (GBHP), ketetapan musyawarah santri, peraturan santri, struktur organisasi, program kerja pengurus pesantren, kalender akademik, jadwal ta'lim, daftar dewan asatiż dan santri, bacaan-bacaan żikir, șalawat, nażam, data di server flashdisk, data di website dan lain-lain.

Sebelum melakukan penelitian, peneliti melakukan beberapa tahap di antaranya, persiapan penelitian, peneliti merumuskan terlebih dahulu masalah yang akan diteliti kemudian didiskusikan dengan dosen pembimbing akademik untuk diangkat menjadi tema dalam penelitian. Pada saat penelitian, tahap ini peneliti mengambil data dengan teknik wawancara, observasi dan dokumentasi. Adapun pada tahap pasca penelitian, peneliti mengolah data yang telah didapat dengan teknik reduksi data, display data, koding data dan penarikan kesimpulan / verifikasi (conclusion drawing / verification). Untuk menguji keabsahan data maka peneliti melakukan uji kredibilitas data dengan melakukan meningkatkan ketekunan, triangulasi, menggunakan bahan referensi dan member check. Setelah itu peneliti menarik kesimpulan kemudian menyusun dan memublikasikan laporan penelitian.

\section{HASIL DAN PEMBAHASAN}

\section{Profil PPM Miftahul Khoir Bandung}

Pesantren Miftahul Khoir didirikan oleh seseorang yang mempunyai hubungan sangat erat dengan para kiai dan pesantren, beliau adalah Bapak H. Ahmad Umar. Pada saat itu beliau bersama KH. Idi Saefudin pendiri Pesantren Al-Falah Dago Bandung sama-sama berada di bawah naungan Partai Majelis Syuro Muslimin Indonesia 
(Masyumi). Beliau mempunyai hubungan erat dengan $\mathrm{KH}$. Choer Affandi yang menyebabkan pesantren yang beliau dirikan sebagian besar dipengaruhi oleh Pondok Pesantren Miftahul Huda Manonjaya Tasikmalaya yang memiliki paham keagamaan Ablus Sunnah Wal Jamäah.

Dhofier (1994:41) melaporkan pesantren pada dewasa ini dapat dikelompokkan menjadi 2 kelompok besar, yaitu : Pertama, pesantren salafi yakni pesantren yang masih mempertahankan pengajaran kitab-kitab Islam klasik sebagai inti pendidikan di pesantren. Kedua, pesantren khalafi yakni pesantren yang telah memasukkan pelajaran-pelajaran umum dalam madrasah-madrasah yang dikembangkannya.

PPM Miftahul Khoir termasuk ke dalam kelompok pesantren salafi. Dari segi pemahaman keagamaan, PPM Miftahul Khoir lebih banyak menginduk kepada Pondok Pesantren Miftahul Huda Manonjaya Tasikmalaya yang menganut paham keagamaan Ablus Sunnah Wal Jamä'ah. Dari segi pendirian dan kepemimpinan di PPM Miftahul Khoir berbeda dengan pesantren salafi pada umumnya, karena pesantren salafi pada umumnya didirikan oleh kiai sekaligus beliau yang menjadi pengasuhnya. Adapun untuk PPM Miftahul Khoir justru kiai-nya didatangkan dari pesantren lain, sehingga menyebabkan belum adanya sosok figur sentral kiai. Secara geografis lokasi PPM Miftahul Khoir berada di dalam perumahan yang merupakan lokasi kondusif sehingga sangat cocok bagi para santri untuk belajar agama.

Secara strategis lokasi PPM Miftahul Khoir berdekatan dengan perguruan tinggi negeri maupun swasta yang ada di Kota Bandung, sehingga bagi mahasiswa yang akan pesantren di PPM Miftahul Khoir tidak akan kesulitan menuju lokasi, karena didukung dengan kendaraan umum yang mudah diakses menuju lokasi meskipun harus jalan terlebih dahulu dari jalan utama untuk bisa sampai ke lokasi. Visi dan misi PPM Mifahul Khoir mempunyai tujuan yang jelas antara urusan agama dan dunia karena visi dan misi tersebut terintegrasi antara ilmu agama dengan ilmu pengetahuan dan teknologi. Materi yang diajarkan di PPM Miftahul Khoir adalah materi keislaman yang mengacu kepada kitab-kitab klasik khas pesantren. Oleh karena itu, PPM Mifahul Khoir merupakan pesantren yang masih mempertahankan ciri khas dalam tradisi pesantren, dan ini menjadi keunggulan tersendiri bagi PPM Miftahul Khoir.

Pendidik yang ada di PPM Miftahul Khoir memiliki keunggulan dengan pendidik yang ada di pesantren pada umumnya, salah satunya berkaitan dengan sanad keilmuan, karena sanad keilmuan pendidik yang ada di PPM Miftahul Khoir beragam, dan itu merupakan sesuatu yang sangat jarang di pesantren salafi pada umumnya. Santri yang ada di PPM Miftahul Khoir termasuk santri mukim. Di sisi lain, santri yang ada di PPM Miftahul Khoir memiliki perbedaan tersendiri dengan santri pesantren salafi pada umumnya, karena mayoritas yang pesantren di PPM Miftahul Khoir adalah para mahasiswa yang sedang belajar di perguruan tinggi, sehingga di samping mereka mencari ilmu di pesantren, mereka juga mencari ilmu di kampus masing-masing. Sebagai lembaga pendidikan Islam, PPM Miftahul Khoir memiliki sarana dan prasarana yang cukup memadai untuk mendukung penyelenggaraan program pendidikannya termasuk dalam mewujudkan visi, misi dan tujuan pendidikan di PPM Miftahul Khoir.

\section{Tujuan Pendidikan Islam di PPM Miftahul Khoir Bandung}

Tujuan pendidikan Islam di PPM Miftahul Khoir terbagi kedalam dua bagian, ada tujuan umum dan tujuan khusus. Tujuan umum pendidikan Islam di PPM Miftahul Khoir adalah dalam rangka melahirkan insan pengabdi Allah, yang beriman, bertakwa, ber-syakhisyyah Islämiyyah, ber-akblakul karimah, dan menjadi kader pemimpin umat yang memiliki tanggung jawab dalam 
mengembangkan dinul Islam sesuai dengan kemampuan ilmu yang diperolehnya.

Tujuan umum pendidikan Islam di PPM Miftahul Khoir selaras dengan Jalal (1988:119) bahwa tujuan pendidikan Islam ialah menjadikan seluruh manusia sebagai abdi atau hamba Allah Subḥ̄nahu Wa Ta'ālâ. Adapun Nashir (2010:39) menegaskan tugas kependidikan dalam Islam berkaitan erat dengan tugas kekhalifahan di muka bumi. Oleh karena itu, Rizal (2014:99) memastikan khalifah dituntut untuk memiliki keterampilan memelihara alam dan kehidupan. Kemampuan hidup selaras dengan aturan-aturan Allah Subhānabu Wa Ta'alâ, baik dalam berfikir, bersikap maupun berperilaku.

Tujuan umum pendidikan Islam di PPM Miftahul Khoir memiliki ciri khas dalam mewujudkan kader pemimpin umat yang memiliki karakter Syakhșiyyah Islämiyyah yakni dengan menjadikan pola pikir dan pola sikap sesuai ajaran Islam dan mengembangkan dinul Islam sesuai dengan kemampuan ilmu yang diperolehnya. Tujuan umum pendidikan Islam di PPM Miftahul Khoir jika melihat input santri sebagai mahasiswa memiliki keunggulan dibandingkan santri salafi pada umumnya, karena santri di PPM Miftahul Khoir bukan saja dituntut memahami ilmu agama Islam saja, tetapi mereka dituntut untuk menjadi kader pemimpin umat dengan memiliki ciri khas Syakbșiyyah Islämiyyah.

Tujuan khusus pendidikan di PPM Miftahul Khoir tidak menargetkan santri untuk menguasai penuh semua ilmu yang ada di pesantren, karena santri yang ada di PPM Miftahul Khoir bukanlah santri murni yang belajar penuh di pesantren, tetapi mereka juga adalah seorang mahasiswa, sehingga konsentrasi mereka dalam belajar terbagi antara kuliah dan pesantren. Oleh karena itu, tujuan khusus pendidikan di PPM Miftahul Khoir ini untuk mengenalkan ilmu-ilmu dasar kepesantrenan seperi ilmu bahasa Arab, para santri dilatih untuk bisa dakwah di kalangan masyarakat dalam rangka menitipkan Islam ini kepada calon para pemimpin bangsa. Tujuan khusus pendidikan Islam di PPM Miftahul Khoir mengalami perbedaan dengan pesantren pada umumnya, karena pesantren pada umumnya menargetkan santri untuk menguasai penuh ilmu-ilmu kepesantrenan. Tujuan pendidikan Islam di PPM Miftahul Khoir cukup terwujud karena dilengkapi kualitas pendidik yang mumpuni, materi lengkap yang diajarkan, sarana dan prasarana yang memadai. Sehingga tujuan pendidikan Islam di PPM Miftahul Khoir sudah relevan dengan apa yang ada dalam profil PPM Miftahul Khoir.

Tujuan Pendidikan Islam secara umum dan khusus di PPM Miftahul Khoir selaras dengan Rizal (2016:1) bahwa pendidikan tidak identik dengan sekedar proses mentransfer ilmu pengetahuan, karena target didik tidak hanya kepandaian akali, tetapi menargetkan dimensi yang lebih luas pada diri manusia, seperti sikap, watak, perilaku dan keterampilan.

\section{Program Pendidikan Islam di PPM Miftahul Khoir Bandung}

Rancangan program pendidikan Islam di PPM Miftahul Khoir dalam membentuk kepribadian Islami dilandasi dengan empat konsep dasar yaitu : Pertama, mengenal dasar-dasar ilmu kepesantrenan. Kedua, Tafaqqub Fiddin. Ketiga, kepemimpinan dan kewirausahaan. Keempat, adab dan etika.

Mastuhu (1988, hlm. 206) dalam Dian Nafi dkk, (2007:49) melaporkan pesantren sebagai sebuah lembaga pendidikan mempunyai tujuan pendidikan yang dirumuskan dengan jelas sebagai acuan program-program pendidikan yang diselenggarakannya.

Empat konsep dasar program pendidikan Islam di PPM Miftahul Khoir dirumuskan dengan jelas untuk menjadi acuan program-program pendidikan yang akan diselenggarakannya, sehingga empat konsep dasar program tersebut selaras dengan Mastuhu. Rancangan program pendidikan Islam di PPM Miftahul Khoir 
memiliki ciri khas dengan memiliki rujukan empat konsep utama dalam merancang program pendidikan Islam. Konsep tersebut menjadikan program di PPM Miftahul Khoir berbeda dengan program pendidikan Islam di pondok pesantren salafi pada umumnya maupun pondok pesantren mahasiswa lainnya. Program pendidikan Islam di PPM Miftahul Khoir akan mendukung terlaksananya tujuan pendidikan Islam di PPM Miftahul Khoir, karena program tersebut dibuat sesuai dengan tujuan pendidikan yang ingin dicapainya. Program pendidikan Islam di PPM Miftahul Khoir terbagi kedalam dua lingkup program, yakni program yang tercantum dalam silabus dan program non-silabus.

Program silabus yang ada di PPM Miftahul Khoir berbeda dengan program pesantren salafi pada umumnya, karena program silabus yang ada di PPM Miftahul Khoir ada penyederhanaan dalam segi kurikulum dan jadwal ta'lim, penyederhanaan tersebut dikarenakan mayoritas santri di PPM Miftahul Khoir adalah mahasiswa. Meskipun ada penyederhanaan, tetapi hampir semua fan ilmu dipelajari di PPM Miftahul Khoir khususnya fan ilmu yang mencakup bidang 'aqidah, syariah dan akhlak. Program silabus dibuat per-kelas, adapun untuk pembagian kelas yang ada di PPM Miftahul Khoir berbeda dengan pembagian kelas dengan pesantren salafi pada umumnya. Karena kelas yang paling tinggi di PPM Miftahul Khoir adalah sampai Wusțo, sedangkan jika kita merujuk kepada pesantren salafi pada umumnya, biasanya kelas yang paling tinggi adalah sampai $M a^{\prime}$ had Aly.

Program non-silabus sangat membantu dalam pembentukan pribadi peserta didik, karena program tersebut dilaksanakan selain di kelas, tetapi dilaksanakan di masjid, asrama, aula, lapang, dan sekitar lingkungan PPM Miftahul Khoir sehingga sangat membantu dalam rangka mewujudkan tujuan pendidikan Islam di PPM Miftahul Khoir. Program non-silabus yang ada di PPM Miftahul Khoir justru merupakan program yang sangat dominan dalam rangka membentuk kepribadian Islami, salah satunya dalam bidang kepemimpinan, para santri selalu dilibatkan dalam kepanitaan agenda Peringatan Hari Besar Islam (PHBI) dan beberapa santri ada yang menjadi pengurus santri. Dalam menjalankan tugas sebagai pengurus santri, para santri akan belajar menghadapi berbagai persoalan yang dihadapi ketika menjalankan programnya, baik itu persoalan dengan pesantren maupun persoalan dengan kuliah, karena di samping mengurus santri, mereka juga harus membagi pikiran, tenaga dan waktu dengan tugas mereka yang ada di kampus.

Di sisi lain, dari rancangan program silabus dan non silabus yang dibentuk, akan adanya kedekatan guru dan murid secara emosional. Rizal (2012:6) menegaskan kedekatan emosional antara guru dan santri akan terbentuk, yang pada gilirannya akan terbangun proses identifikasi. Santri secara inisiatif belajar tentang nilai-nilai kehidupan melalui proses penilaian kepada orang yang dikaguminya. Oleh karena itu, kiai sebagai sosok yang dikaguminya akan menjadi teladan bagi para santrinya.

Pelaksanaan pendidikan Islam di PPM Miftahul Khoir Bandung dalam membentuk kepribadian Islami terbagi kedalam dua pelaksanaan program yakni program yang tercantum dalam silabus dan non-silabus. Untuk program yang tercantum dalam silabus dilaksanakan dalam ta'lim rutin setiap hari yang dilaksanakan $b a^{\prime} d a$ Subuh sampai pukul 06.00 dan ba'da Maghrib sampai pukul 20.30. Pelaksanaan ta'lim tersebut terbagi ke dalam tiga kelas yakni I'dād, Ibtidā dan Wusțo. Dewan asatiż menggunakan metode pengajaran yang berbeda-beda, karena dewan asatiż yang ada di PPM Miftahul Khoir terdiri dari latar belakang pendidikan yang berbeda-beda, ada yang lulusan pesantren tradisional murni dan ada yang lulusan perguruan tinggi.

An-Nahlawi melaporkan dalam Tafsir (2014:131) bahwa ada beberapa metode untuk menanamkan rasa keimanan, 
di antaranya metode hiwar, metode kisah Qurani dan Nabawi, metode Amśal (perumpamaan) Qurani dan Nabawi, metode Keteladanan, metode pembiasaan, metode Tbrah dan Mau'iżah, dan metode Targhib dan tarbib.

Metode pengajaran yang dilaksanakan di PPM Miftahul Khoir selaras dengan An-Nahlawi yakni dengan menggunakan metode pendidikan Islam untuk menanamkan rasa keimanan. Karena pendidikan Islam akan selaras jika disampaikan dengan menggunakan metode pendidikan Islam, dan itu berbanding terbalik jika menggunakan metode pendidikan Barat, karena dalam dunia Barat selalu mengagungkan metode ilmiah yang segala sesuatunya harus terukur dengan data secara terindra.

\section{Pelaksanaan Pendidikan Islam di PPM Miftahul Khoir Bandung}

Pelaksanaan pendidikan Islam di PPM Miftahul Khoir dalam membentuk kepribadian Islami sudah sesuai dengan program yang ada di silabus yakni berbentuk ta'lim dan non-silabus dengan menggunakan berbagai macam metode pengajaran di antaranya menggunakan metode talaqi, ceramah, sorogan, hafalan, diskusi, tanya jawab, latihan, targhib wa tarbib, pengawasan, uswätun basanah, pembiasaan, pembacaan syair dan wirid. Metode uswātun basanah yang dicontohkan dewan asatiż dalam melaksanakan peribadahan akan lebih efektif dan berkesan dalam diri santri dalam rangka membentuk kepribadian Islami, karena santri akan mencontoh dan meneladani gurunya bersikap.

Pelaksanaan program pendidikan para santri di PPM Miftahul Khoir terbagi kedalam aktivitas harian, mingguan, bulanan dan tahunan. Program non-silabus yang ada di PPM Miftahul Khoir memiliki perbedaan dengan program pesantren salafi pada umumnya, salah satunya program nonsilabus yang ada di PPM Mifthaul Khoir mempunyai kelebihan dari segi pembiasaan
Șalat berjama'ah awal waktu di masjid, menjaga kebersihan dan selalu menjaga kebersamaan sesama santri. Pelaksanaan pendidikan Islam di PPM Miftahul Khoir sudah relevan dengan program yang dibuatnya, meskipun ada program yang belum terlaksana dengan baik di antaranya ketika ada program agenda bersama seluruh santri dan dakwah Islam di masyarakat, kendalanya karena para santri yang ada di PPM Miftahul Khoir adalah para mahasiswa, sehingga waktu mereka terkadang bentrok dengan agenda kampus dan waktu mereka terbatas untuk terjun ke masyarakat, karena disamping sibuk di pesantren, mereka juga sudah disibukan dengan aktivitas di kampusnya. Sehingga diperlukan adanya skala prioritas dalam pelaksanaan agenda pesantren dan agenda kampus.

\section{Evaluasi Pendidikan Islam di PPM Miftahul Khoir Bandung}

Tujuan diadakan evaluasi pendidikan Islam di PPM Miftahul Khoir dalam rangka mengetahui hasil dari proses pembelajaran selama satu semester, sehingga akan menjadi tolak ukur penyelenggaraan ta'lim yang lebih baik pada semester berikutnya. Evaluasi di PPM Miftahul Khoir dinamakan imtihan atau ujian. Adapun teknik evaluasi yang digunakan di PPM Miftahul khoir terdiri dari teknik tes tulis, hafalan dan praktek. Pelaksana evaluasi di PPM Miftahul khoir diserahkan kepada dewan asatiż dalam membuat soal, adapun pengurus pesantren memfasilitasi dewan asatiż dalam pelaksanaan secara teknis. Pengurus pesantren akan meminta hasil dari ujian tersebut untuk direkap dan diumumkan hasilnya pada saat pelaksanaan muäda'ah. Pihak yang terlibat dalam pelaksanaan evaluasi di PPM Miftahul Khoir adalah pihak yayasan, pengasuh, dewan asatiż dan pengurus pesantren.

Anwar \& Fakhruddin (2016) menegaskan istilah pengukuran identik dengan evaluasi yang bersifat kuantitatif. Sementara penilaian bersifat kualitatif. 
Sedangkan evaluasi mencakup kegiatan mengukur dan menilai.

Evaluasi yang dilakukan di PPM Miftahul Khoir selaras dengan definisi evaluasi yang ditegaskan Anwar dan Fakhruddin. Evaluasi pendidikan Islam di PPM Miftahul Khoir cukup memenuhi kriteria dalam evaluasi, di samping mengukur dengan evaluasi kuantitatif yang diselenggarakan setiap akhir semester, evaluasi di PPM Miftahul Khoir juga diadakan penilaian seperti dalam kepribadian santri sehari hari yang sifatnya tidak formal, meskipun evaluasi dalam ranah kepribadian belum berjalan secara sistematis tetapi pengasuh langsung memberikan teguran di tempat jika ada santri yang melanggar aturan Islam dan pesantren. Pada umumnya evaluasi yang dilakukan di PPM Miftahul Khoir memiliki kesamaan dengan evaluasi di pesantren salafi pada umumnya, meskipun evaluasi yang ada di PPM Miftahul Khoir masih terbatas pada evaluasi di akhir semester saja.

Sistem evaluasi yang ada di PPM Miftahul Khoir belum mencakup evaluasi kepribadian secara sistematis, karena evaluasi yang dilakukan baru dari ranah ta'lim dan itu juga diadakan satu semester sekali. Teknik evaluasi yang digunakan di PPM Miftahul khoir terdiri dari teknik tes tulis, hafalan dan praktek. Dalam pelaksanaannya, fungsi evaluasi yang ada di PPM Miftahul Khoir baru berjalan evaluasi dari segi pendidik, peserta didik dan pembuat kebijakan yakni pengurus pesantren sendiri. Dari hasil evaluasi tersebut, akan menjadi tolak ukur pendidik untuk mengajar di semester selanjutnya, adapun untuk peserta didik khususnya santri, dari segi pengetahuan evaluasi tersebut belum bisa menjadi tolak ukur keberhasilan santri, karena evaluasi rutin yang dilakukan hanya di akhir semester saja.

Adapun evaluasi santri dari segi kepribadian, evaluasi tersebut bisa menjadi bahan intropeksi santri dalam berprilaku kedepannya. Untuk pembuat kebijakan dalam hal ini adalah pengurus pesantren, evaluasi tersebut dijadikan tolak ukur untuk membuat program yang lebih baik lagi di semester selanjutnya. Evaluasi yang ada di PPM Miftahul Khoir dirasa masih kurang dalam rangka menilai tujuan pendidikan Islam dan program pendidikan Islam di PPM Miftahul Khoir, karena evaluasi yang terencana baru sebatas evaluasi dari segi pengetahuan, adapun dari segi kepribadian santri belum adanya sistem evaluasi yang sistematik. Itu semua disebabkan karena dewan asatiż yang ada di PPM Miftahul Khoir tidak tinggal di pesantren, sehingga menyebabkan kurangnya pengawasan dari dewan asatiż. Di sisi lain, belum adanya sosok figur sentral kiai yang ada di PPM Miftahul Khoir sebagai sosok yang memiliki wibawa kiai dan diteladani oleh para santri.

\section{Keberhasilan Pendidikan Islam di PPM Miftahul Khoir Bandung}

Keberhasilan pendidikan Islam di PPM Miftahul Khoir itu bisa dilihat dari perkembangan kepribadian Islami yang ada dalam diri santri. Adapun karakteristik kepribadian Islami yang diambil dalam penelitian ini adalah karakteristik kepribadian Islami yang dirumuskan oleh Syaikh Hasan Al-Banna dalam Isa \& Manshur (2017) melaporkan yakni ada $10 \mathrm{di}$ antaranya : Pertama, dalam bidang 'Aqidah Islam para santri di PPM Miftahul Khoir memiliki kesamaan paham 'Aqidab dengan pesantren salafi pada umumnya yakni dengan mempelajari kitab 'Aqidah yang merujuk kepada paham Ablus Sunnab $W$ al Jamäah. Kedua, dari segi ibadah, program pendidikan Islam di PPM Miftahul Khoir cukup berhasil membentuk para santri untuk beribadah dengan benar, karena para santri belajar ibadah dalam Ta'lim Fiqh menggunakan kitab Safinātunnaja dan Fathul Qarib yang merujuk kepada Figh Imam Syafi'i rahimähullāh, sehingga para santri akan mengetahui syarat, rukun dan mencontoh ibadah yang dilakukan oleh Rasulullah Șallâ Allah 'Alaibi Wa Sallam melalui metodologi pemahaman mażhab Imam Syafi'i 
rahimähulläh. Ketiga, dari segi akhlak, santri di PPM Miftahul Khoir memiliki akhlak santri yang kokoh salah satunya untuk selalu bersikap husnuíon dan penghormatan kepada ilmu, sumber ilmu dan perantara yang menyampaikan ilmu. Keempat, dari segi ketangguhan jasmani, santri yang ada di PPM Miftahul Khoir memiliki kesehatan jasmani yang cukup bagus. Kelima, dari segi wawasan, santri yang ada di PPM Miftahul Khoir cukup memiliki wawasan yang luas, karena para santri di PPM Miftahul Khoir terdiri dari berbagai perguruan tinggi, sehingga diantara para santri bisa saling bertukar pemikiran dalam diskusi sehingga dapat membantu mereka dalam membuka wawasan lebih luas lagi.

Keenam, dari segi kemandirian, santri PPM Miftahul Khoir cukup memiliki kemandirian yang baik, karena mereka dituntut untuk melakukan segala aktivitas dengan sendiri. Ketujuh, dari segi keteraturan dalam setiap urusan, santri PPM Miftahul Khoir cukup baik dalam mengatur urusannya, itu bisa dilihat dari status para santri disamping pesantren mereka juga belajar di perguruan tinggi. Kedelapan, dari segi menjaga waktu, santri yang ada di PPM Miftahul Khoir cukup pandai dalam menjaga waktu, apalagi mereka harus belajar menjaga waktu antara kuliah dan pesantren, dan itu sudah terbukti cukup baik. Kesembilan, dari segi kebermanfaat bagi orang lain, beberapa santri PPM Miftahul Khoir sudah mulai terjun ke masyarakat dengan mendidik di sekitar masyarakat, meskipun ada yang belum terjun memberikan manfaat di dunia masyarakat dengan alasan masih mempersiapkan ilmunya, tetapi mereka merasakan ada keresahan dengan keadaan sekitar masyarakat yang tidak sesuai dengan Islam dan berusaha ingin merubahnya lebih baik lagi. Kesepuluh, dari segi menjaga hawa nafsu, sikap santri selalu menjaga pandangan ketika berinteraksi dengan lawan jenis dan beberapa santri mulai menanamkan jiwa selalu busnużon. Keberhasilan pendidikan Islam di PPM Miftahul Khoir sudah relevan dengan tujuan pendidikan Islam di PPM
Miftahul Khoir, meskipun ada tujuan yang belum tercapai dengan baik yaitu para santri belum rajin melaksanakan salat tahajud, dikarenakan aktivitas santri yang padat pada siang hari karena kuliah ditambah dengan jadwal ta'lim pada malam harinya di pesantren, sehingga ketika ada tugas dari kuliahnya biasanya dikerjakan setelah ta'lim sampai larut malam yang menyebabkan para santri tidurnya sebentar dan susah bangun untuk Ṣalat tahajud.

\section{KESIMPULAN}

PPM Miftahul Khoir termasuk ke dalam kelompok pesantren salafi. Dari segi pemahaman keagamaan, PPM Miftahul Khoir lebih banyak menginduk kepada Pondok Pesantren Miftahul Huda Manonjaya Tasikmalaya yang menganut paham keagamaan Ablus Sunnab Wal Jamä'ah. Dari segi pendirian dan kepemimpinan di PPM Miftahul Khoir berbeda dengan pesantren salafi pada umumnya, karena pesantren salafi pada umumnya didirikan oleh kiai sekaligus beliau yang menjadi pengasuhnya. Adapun untuk PPM Miftahul Khoir justru kiai-nya didatangkan dari pesantren lain, sehingga menyebabkan belum adanya sosok figur sentral kiai.

Tujuan umum pendidikan Islam di PPM Miftahul Khoir memiliki ciri khas dalam mewujudkan kader pemimpin umat yang memiliki karakter Syakbșiyyah Islämiyyah yakni dengan menjadikan pola pikir dan pola sikap sesuai ajaran Islam dan mengembangkan dinul Islam sesuai dengan kemampuan ilmu yang diperolehnya. Tujuan khusus pendidikan di PPM Miftahul Khoir tidak menargetkan santri untuk menguasai penuh semua ilmu yang ada di pesantren, karena santri yang ada di PPM Miftahul Khoir bukanlah santri murni yang belajar penuh di pesantren, tetapi mereka juga adalah seorang mahasiswa, sehingga konsentrasi mereka dalam belajar terbagi antara kuliah dan pesantren.

Rancangan program pendidikan Islam di PPM Miftahul Khoir memiliki ciri 
khas dengan memiliki rujukan empat konsep utama dalam merancang program pendidikan Islam. Konsep tersebut menjadikan program di PPM Miftahul Khoir berbeda dengan program pendidikan Islam di pondok pesantren salafi pada umumnya maupun pondok pesantren mahasiswa lainnya. Program pendidikan Islam di PPM Miftahul Khoir akan mendukung terlaksananya tujuan pendidikan Islam di PPM Miftahul Khoir, karena program tersebut dibuat sesuai dengan tujuan pendidikan yang ingin dicapainya. Program pendidikan Islam di PPM Miftahul Khoir terbagi kedalam dua lingkup program, yakni program yang tercantum dalam silabus dan program non-silabus.

Pelaksanaan pendidikan Islam di PPM Miftahul Khoir dalam membentuk kepribadian Islami sudah sesuai dengan program yang ada di silabus yakni berbentuk ta'lim dan non-silabus dengan menggunakan berbagai macam metode pengajaran di antaranya menggunakan metode talaqi, ceramah, sorogan, hafalan, diskusi, tanya jawab, latihan, targhib wa tarbib, pengawasan, uswātun basanah, pembiasaan, pembacaan syair dan wirid. Metode uswätun hasanah yang dicontohkan dewan asatiż dalam melaksanakan peribadahan akan lebih efektif dan berkesan dalam diri santri dalam rangka membentuk kepribadian Islami, karena santri akan mencontoh dan meneladani gurunya bersikap.

Evaluasi pendidikan Islam di PPM Miftahul Khoir cukup memenuhi kriteria dalam evaluasi, di samping mengukur dengan evaluasi kuantitatif yang diselenggarakan setiap akhir semester, evaluasi di PPM Miftahul Khoir juga diadakan penilaian seperti dalam kepribadian santri sehari hari yang sifatnya tidak formal, meskipun evaluasi dalam ranah kepribadian belum berjalan secara sistematis tetapi pengasuh langsung memberikan teguran di tempat jika ada santri yang melanggar aturan Islam dan pesantren.

Keberhasilan pendidikan Islam di PPM Miftahul Khoir cukup berhasil dalam membentuk kepribadian Islami diantaranya Salimul 'Aqidah, Sahihul Ibadah, Matinul Khuluq, Qawiyyul Jismi, Musaqqaful Fikeri, Qadirun Alal Kasbi, Munazzamun Fì Syu'ünih, Harișun Ala Waqtibi, Näfi'un Lighairibi, dan Mujäbidun Linafsibi. Itu semua bisa dilihat dari perkembangan kepribadian Islami yang ada dalam diri sendiri pada kegiatan seharihari.

\section{DAFTAR PUSTAKA}

Abdussalam, A. (2014). Teori Sosiologi Islam (Kajian Sosiologis terhadap Konsep-konsep Sosiologi dalam Alquran Al-Karim). Ta'lim, 12(1), 25-40.

Abdussalam, A. (2011). Paradigma tauhid: kajian paradigma alternatif dalam pengembangan ilmu dan pembelajaran. Jurnal Pendidikan Agama Islam-Ta'lim, 9(2), 113-126.

Tafsir, A. (2014). Ilmu Pendidikan Dalam Perspektif Islam. Bandung: Remaja Rosdakarya.

Ali, M. (2013). Penelitian Kependidikan \& Strategi. Bandung: Angkasa.

Anwar, S., \& Fakhruddin, A. (2016). Pelaksanaan Standar Penilaian oleh Guru Pendidikan Agama Islam di Sekolah ( Studi Evaluatif terhadap Guru PAI SMP dan SMA di Bandung ). Jurnal Pendidikan Agama Islam-Ta'lim, 14(2), 139-155.

Basrowi, S. \&. (2009). Memahami Penelitian Kualitatif. Jakarta: Rineka Cipta. Jakarta: Rineka Cipta.

Brannen, J. (2005). Memadu Metode Penelitian Kualitatif dan Kuantitatif. Yogyakarta: Pustaka Pelajar.

Daradjat, Z. (2006). Ilmu Pendidikan Islam. Jakarta: Bumi Aksara.

Dhofier, Z. (1994). Tradisi Pesantren. Yogyakarta: LP3ES.

Dian Nafi dkk. (2007). Praksis Pembelajaran Pesantren. Yogyakarta: LKis Pelangi Aksara. Yogyakarta: LKis Pelangi Aksara.

Fahrudin. (2011). Peranan Pendidikan 
Agama Dalam Keluarga Terhadap Pembentukan Kepribadian Anak. Jurnal Pendidikan Agama Islam-Ta'lim, 9(1), 1-16.

Hakim, Y. R. (2013). Pola Pendidikan Islam

Dalam Membentuk Karakter Disiplin (Studi Deskriptif di SMK Daarut Tauhiid Boarding School Tahun Ajaran 2012/2013). Bandung: Universitas Pendidikan Indonesia.

Hamdi. (2016). Narkoba di Kalangan Mahasiswa Dikendalikan dari Bui Jakarta. Retrieved February 5, 2017, from

https://m.tempo.co/read/news/20 16/09/22/064806517/narkoba-dikalangan-mahasiswa-dikendalikandari-bui-jakarta

Isa \& Manshur, M. H. (2017). Syarah 10 Muwashafat; Penjelasan Lengkap 10 Karakter Muslim Tangguh. (Ghufron, Ed.). Laweyan: Era Adicitra Intermedia.

Jalal, A. F. (1988). Azas-Azas Pendidikan Islam. Bandung: Diponegoro.

Kurniawan, B. (2016). Sasongko Kemas Miras Beraneka Rasa, Pelanggan Mahasiswa dan Kalangan Bawah. https://doi.org/http://news.detik.c om/berita/3137620/sasongkokemas-miras-beraneka-rasapelanggan-mahasiswa-dan-kalanganbawah

Langgulung, H. (1985). Pendidikan dan Peradaban Islam (Suatu Analisa Sosio-Psikologi). Jakarta: Pustaka Al Husna.

Muhadjir Effendi, D. (2002). Dinamika Pemikiran Islam di Perguruan Tinggi. Jakarta: Logos Wacana Ilmu dan Pemikiran.

Nashir, R. (2010). Mencari Tipologi Format Pendidikan Ideal Pondok Pesantren di
Tengah Arus Perubahan. Yogyakarta: Pustaka Pelajar.

Nata, A. (2011). Ilmu Pendidikan Islam. Jakarta: Kencana Prenada Media Group.

Nurlaila. (2011). Model-Model Pengembangan Pendidikan Agama Islam Di Sekolah/Perguruan Tinggi. Ta'dib, 16(2), 248-272.

Rizal, A. S. (2012). Pendidikan Nilai Secara Active-Learning Dalam Tradisi Pondok Pesantren. Jurnal Pendidikan Agama Islam - Ta'lim, 10(1), 1-12.

Rizal, A. S. (2014a). Filsafat Pendidikan Islam Sebagai Landasan Membangun Sistem Pendidikan Islami. Jurnal Pendidikan Agama Islam - Ta'lim, 12(1), 1-18.

Rizal, A. S. (2014b). Perumusan Tujuan Sebagai Basis Pengembangan Kurikulum Pendidikan Islam. Jurnal Pendidikan Agama Islam - Ta'lim, 12(2), 97-112.

Rizal, A. S. (2016). Ilmu sebagai substansi esensial dalam epistemologi pendidikan islam. Jurnal Pedidikan Agama Islam - Ta'lim, 14(1), 1-17.

Syahidin. (2009). Menelusuri Metode Pendidikan Dalam al-Quran. Bandung: Alfabeta.

Wiyono, A. S. (2014). Pengakuan Mahasiswa Bandung Kecanduan Seks Bebas di Kos. Retrieved February 5, 2017, from https://www.merdeka.com/peristi wa/pengakuan-mahasiswabandung-kecanduan-seks-bebas-dikos-hotel.html

Yusanto Dkk, M. I. (2014). Menggagas Pendidikan Islami: Dilengkapi Implementasi Praktis Pendidikan Islam Terpadu di TK, SD dan SMU. Bogor: Al-Azhar Press. 